IQTISHADIA

12,2

240

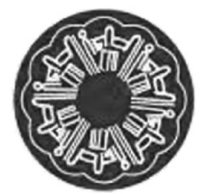

Vol. 12 (2) 2019

PP. 240-265

P-ISSN: $1979-0724$

E-ISSN: $2502-3993$

DOI : $10.21043 /$ iqtishadia.v12i2.4992

\section{Mashlaha in Financing Risk Measurement in Sharia Financing Institutions ${ }^{1}$}

\author{
Salmah Said ${ }^{*}$, A. Syathir Sofyan ${ }^{2}$, \\ Andi Muhammad Ali Amiruddin ${ }^{3}$ \\ UIN Alauddin Makassar ${ }^{1,2,3}$ \\ salmahsaid@uin-alauddin-ac.id's syathir_sofyan@yahoo.com², \\ andiamiruddin@uin-alauddin.ac.id ${ }^{3}$
}

\begin{abstract}
The crisis of confidence in the credit rating agency forced Islamic financing institutions to apply risk measurement methods independently and renewed the study of credit risk measurement. Moreover, this research also discusses mashlaha (public interest) in measuring financing risk. This research uses a mixed method approach, combining quantitative methods to measure risk by utilizing CreditRisk+, and qualitative methods in analyzing mashlaha in these measurements. This study revealed that CreditRisk+ is able to measure financing risk accurately. This study also found that there is mashlaha as part of maqashid al-sharia in risk measurement, namely 1) Tahdzib al-Fard, that makes a financial institution capable of independently measuring the risk of its own financing; 2) Iqamah al-Adl, independent measurement will create information justice by comparing measurement results both internally and externally. 3) Mashlaha itself, with internal risk measurement, will reduce systemic risk. The implications of this study is the use of mashlaha in analyzing financing risk provides more stringent prudential in the measurement of financing risk.
\end{abstract}

\section{Keywords:}

Risk measurement, CreditRisk+, Mashlaha

\section{INTRODUCTION}

The global financial crisis began with the collapse of the financial sector in America in 2008. The fall in the value of the assets of the housing sector resulted in the default of subprime mortgage debtors. Obviously, credit risk shown its significant role in the global financial crisis (Bodnar, et.al., 2011). This default risk highlighted the importance of measurement of credit risk (Allen and Powell, 2011). This was preceded by an accommodative government policy of facilitating loan application conditions, supported by a long-term trend of increasing house prices, encouraging high-risk lending practices hoping to refinance at lower interest rates (Direktur Bank Indonesia, 2008).

1 Part of this article, which particularly deals with Credit Risk Analysis, has been presented at Konferensi Nasional Ke-6 Asosiasi Program Pascasarjana Perguruan Tinggi Muhammadiyah, Pare-pare, 2017. The present article is further analyzed using Abu Zahrah's concept on Maqashid al-Sharia.

*corresponding author 
In addition, the practice of shadow banking also contributed to the global financial crisis (Rachmati, 2012). Shadow banking is a financial institution that conducts credit distribution which includes entities and activities, both whole or in part, outside the banking system regulation (Financial Stability Board, 2011).

In Indonesia, shadow banking is a Non-Bank Financial Services Institution (LJKNB) (Adriyanto, 2012), which is still in the development stage. The case of LJKNB in Indonesia can be seen in lending for the ownership of motorized vehicles. The ease of the vehicle loan application requirements and the light down payment offered by the finance company attracts consumers to apply for credit. This results in the emergence of unfair competition between companies in determining the down payment. This, in turn, causes the occurrence of default risk, which is the inability of the borrowers to repay the loan on time or the default of debtor (Spuchl'áková, et.al., 2015; Basel Committee on Banking Supervision, 2011; Savvides, 2011; Misman and Bhatti, 2010; Bauer and Hann, 2010; Drehmann and Nikolaou, 2009). This kind of risk is an example of risk Level I (Kuritzkes, et.al., 2002). To mitigate this, the Minister of Finance then, responded to this condition by issuing a regulation on minimum down payment requirements for motorized vehicles, both two-wheeled and four-wheeled vehicles for consumer financing listed in the Republic of Indonesia Minister of Finance Regulation Number 43 /PMK.010/ 2012 (Winardi, 2013; Wibisono, 2013).

Islamic financial institutions in Indonesia, and indeed in other countries, tend to implement a financing system with the murabahah principle scheme (Ascarya, 2006; Faisal, 2011; Alamsyah, 2012; Lathif, 2012; Makkulau and Abdullah, 2017; Rahman et al., 2010). According to Misman and Bhatti (2010), credit risk is a major risk faced by several types of financing (i.e. murabahah, ijarah thumma al-bay, bay al-enah, tawarruq, and commodity murabahah) provided by Islamic banks, though it is an unsystematic risk. The principle of this financing equals lending at conventional financing institutions. Even, credit risk management of Islamic financial institutios face more complicated cases, both internal and particularly external factors, such as no penalty charged on default payment by debtors (Misman and Bhatti, 2010). Thus, it is believed that Islamic finance institutions require measurement of financing risk as well as other conventional ones. To mitigate financing risks, sharia financial institutions can take precautionary measures by implementing proactive risk management so that financial institutions are able to have long-term business continuity (Manan and Shafi'ai, 2015). In 
IQTISHADIA

12,2

242

addition, independent security (a specific credit risk management model) is also needed as a form of security for sharia risks channelled by banks and LJKNB, including sharia financing institutions (Oswari, 2008).

Islamic financial institutions do not have a standard practice for calculating financing risk. Instead they either calculate the risk themselves using the Non Performing Financing method alone, or they use a credit rating agency, which measures credit risk in financial institutions (Dhruba, 2018). Thus, to measure the potential risk of financing for sharia financial institutions, an independent method which can be widely applied in the calculation of financial risk is needed. Some previous researchers such as Fitri (2004) and Rochman (2010) show that CreditRisk+ is quite valid in measuring the risk of financing in Islamic banks. Another study conducted by Olof (2006) and Melaini (2010) on two-wheeled vehicle credit financing institutions shows the same results. These researchers concluded that the characteristics of CreditRisk+ are suitable for calculating financing risk in Islamic finance institutions that have many debtors.

According to Crouchy, et.al. (2000) the CreditRisk+ method is relatively easy to implement and one of very common industry models in calculating credit risk (Fischer, et.al., 2018; Spuchláková, et.al., 2015; Pirotte, et.al., 2004). Credit Risk+ uses a Poisson variable to provide analytic solution (Fischer, et.al., 2018). In addition, the methodology assumes that financing risk is not directly related to market risk or the magnitude of exposure of each permanent debtor, and is insensitive to changes in interest rates. Further research is needed in different places because the assumption of an independent sector in CreditRisk+ is a major obstacle in implementing the model (Han and Kang, 2014). Furthermore, the foundation of CreditRisk+, i.e. the Poisson distribution theory, is still being developed today. The validity of a financing risk measurement model is the main focus of the discussion of the above literature. Meanwhile, the discussion of the benefit of the model has not been studied further. Measuring the risk of financing with CreditRisk+ only provides information on risk security, which indicates a warning against such losses (Sofyan, 2017). Problems also arise, is the measurement of financing risk carried out after default? Given that CreditRisk+ is the default mode (DM) paradigm (Saunders and Allen, 2002).

This research study becomes challenging when the analysis used is a combination of conventional methods and sharia concepts. First, given the measurement of financing risk based on default mode, it does not apply to one of the principles in the rules of fiqh, dar ul mafasid muqaddam ala 
jalb al masalih which prioritize prevention rather than calculating the risk later. As Manana, and Shafi'ai (2015) promoted that Islamic religion has fundamental principles that oblige its followers to maintain religion, soul, intellect, heredity, and wealth, broad-based economic welfare is one of the achievements expected from its financial systems. For this reason, risk management is a pillar in realizing a good Islamic financial system. Second, the research of Radzi and Ku Lonik (2016) discussed sharia rating agencies and their solutions for Islamic banking. This certainly raised the question why do financial institutions not measure risk by applying independent methods. For this reason, it is necessary to analyse the measurement of financing risk in the frame of mashlaha. Unlike previous research that analyzes financing risks by utilizing only conventional tools, our study not only uses CreditRisk+ and but also uses the concept of mashlaha, a sharia concept. The mashlaha concept is used to assess the importance of risk analysis.

\section{LITERAL REVIEW}

\section{CreditRisk+}

Measurement of credit or financing risk is very important as a preventive and anticipatory step for finance companies in anticipating the potential of default customers. There are two approaches used in measuring credit risk, namely Default Mode (DM) and Market to Market Mode (MTM). In the default approach the credit performance mode is categorized as default and non-default, which emphasizes the calculation of the expected loss and unexpected loss. In the MTM approach the focus is on macroeconomic values that affect credit performance and the amount of credit loss will decrease if there is a downgrade or vice versa (Saunders and Allen, 2002). From several credit risk calculation methods discussed by Saunders (KMV and Moody's, KPMG and Kamakura Corporation, CreditMetrics, CreditPortfolio View and CreditRisk+), only CreditRisk+ is the only pure mode of default mode. Thus, we use this method as an analysis of financing risk measurement.

The CreditRisk + method was first introduced by Credit Suisse Group, in December 1996. This model is an actuarial approach based on insurance literature, namely fire insurance. In fire insurance companies, the amount of loss is determined by two factors: the probability of the house being burned (frequency of event) and the value of the house that is on fire (severity of loss). This idea is analogous to calculating credit risk where the distribution of losses from the loan portfolio is the default frequency of the loan and the value of default credit (severity of loan losses) (Credit Suisse First Boston, 1997). 
IQTISHADIA

12,2

244

The CreditRisk + model is based on a portfolio approach for modelling credit default risk that takes into account information related to the size, duration of exposure, credit quality, and the systematic risk of customers. The CreditRisk+ model is a statistical credit default risk model that does not assume the cause of bankruptcy. This approach is similar to that taken in market risk management, where no effort is made to model the causes of market price movements. In its measurement, CreditRisk+ for a number of portfolios (with the number of exposures from different debtors) uses the band as a criterion or risk class to create a sub-portfolio. CreditRisk+ uses an analytical framework that makes measurement easy and uses numerical logarithmic calculations (Credit Suisse First Boston, 1997).

Figure 1. Calculation Process in CreditRisk + Model

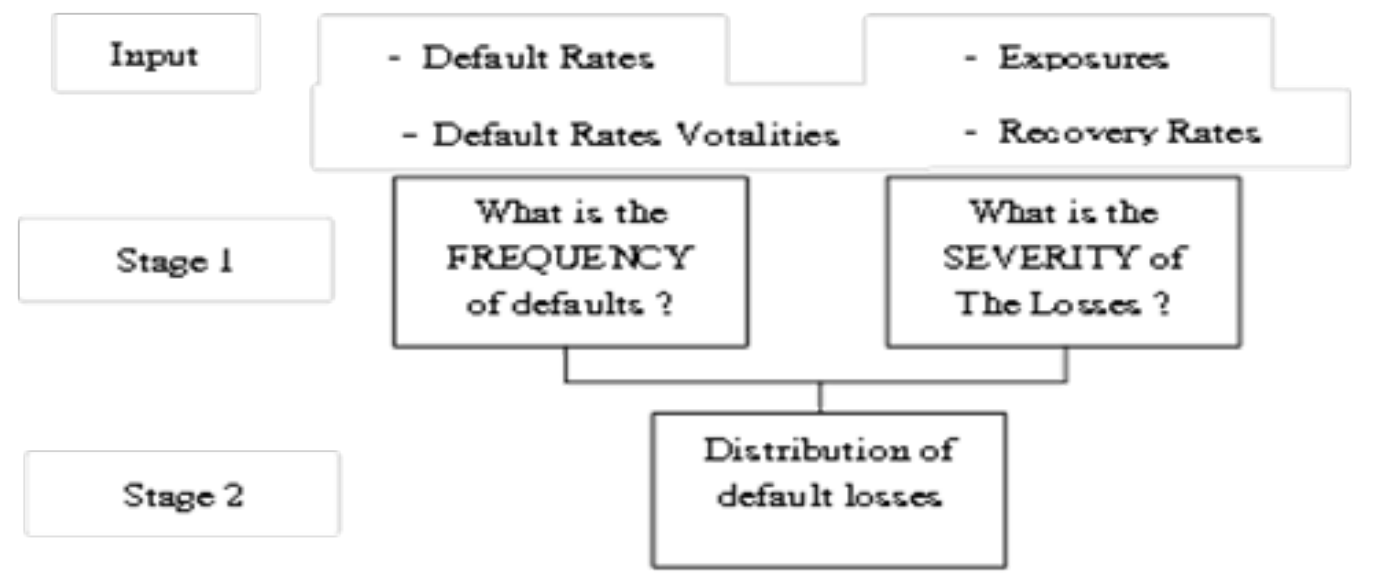

Source: (Credit Suisse First Boston, 1997)

\section{Maqashid al-Sharia and Mashlaha}

Maqashid al-sharia consists of the word maqashid which is the plural form of the word maqsad which means the goal to be achieved from mediating human activities. While sharia means the road to water sources or roads leading to the source of life (Ati, 2007). Ibn Zugaibah 'Izzuddin (1996) defines the word maqashid, which means al hikmah (wisdom), or ma'na (meaning), illat, reasonable (fit), and mashlaha or importance. Al-Ghazali (450-505 H) defined it as al-mashlaha, which is a fundamental explanation of something that benefits or destroys the merit, by maintaining five fundamental principles of sharia: the religion (nafs) soul), 'aql (intellectual), nasl (heredity) and wealth. Al-Syatibi $(720-790 \mathrm{H})$ concluded that the maqashid al-sharia is the goal of maintaining the purpose of sharia that is revealed to the creatures, in order not to escape from the three basic interests: dharuriyat, hajiyat and tahsiniyat. Allah SWT points out something meant to preserve the value 
of the world and the hereafter.The dharuriyat aspect is known as the aldharuriyat al-khamsah terminology (five things that are very important): maintaining religion, soul, mind, lineage and safeguarding property.

While Abu Zahrah has three foundations in the maqashid al-sharia: tahdzib al-fard (educating invididu), iqamah al-adl (justice enforcement), and al-mashlaha (public interest) (Mohammad and Shahwan, 2013). The second basic interest is hajiyat which is something that is needed by humans for spaciousness and breadth, bearing the burden of taklif and other burdens of life. If these needs do not materialize, they do not threaten safety, but human beings will experience difficulties. The last is tahsiniyat, which etymologically means perfecting or improving things. The level of this need is in the form of complementary needs. If this need is not met, it will not threaten nor cause difficulties (al-Syatibi, 720-790 H).

In addition to al-Syatibi, Abu Zahrah (1997) argued that there are three objectives in maqashid al-sharia: 1) Tahdzib al-Fard (educating individuals), 2) Iqamah al-Adl (enforcement of justice), and 3) al-Mashlaha (public interest). Some literature uses this framework in measuring the performance of Islamic banks called Performance Measures Based-Maqasid al-Sharia Framework (PMMS) such as Mohammad and Shahwan (2013), and Jazil and Syahruddin (2013).

The term tahdzib in the first objective shows the spread of knowledge and skills, as well as instilling in individuals values for the spiritual development of sharia financial institutions, so that they must design education and training programs to develop a knowledgeable and skilled workforce that is imbued with the right moral values. They also have to disseminate information that will inform stakeholders about their products. The second objective is al-adl (justice), as all business activities are based on justice, including products, prices, terms of contract, and information. It must also ensure that all business ventures are free from negative elements that can create injustices, such as usury (including interest), fraud, corruption and others. With regard to the third goal, mashlaha or Islamic interests of sharia, financial institutions must give priority to business activities that produce greater benefits to the general public. This includes activities in areas related to basic community needs such as investments in vital sectors, housing project financing, and others. These three goals (education, justice and mashlaha) are maqashid in general (Mohammad and Shahwan, 2013). 
IQTISHADIA

12,2

246

The discussion of maqashid al-sharia cannot be separated from mashlaha. Mashlaha means goodness, which means loss of damage (Ibn Manzur, 1994). Louis Ma'lūf (1987) defined mashlaha as something that brings goodness, namely human actions which can bring benefits to themselves and their people. In fact, al-Ghazali $(450-505 \mathrm{H})$ interpreted the maqashid etymology with al-mashlaha. Ibn Asyur (2001) defined mashlaha as an act which produces good and continuous benefits for many people. In general, it can be understood that etymologically mashlaha is something that brings the achievement of goodness to humans. Every good that is attributed to humans is considered mashlaha (Akbar and Ahmad, 2016).

Several studies on risk assessment using the CreditRisk+ method have been conducted, such as Fitri (2004); Olof (2006); Kurniawan (2009); Rochman (2010); Melaini (2010); and Sharif et al. (2015). However, the preparation of bands in CreditRisk+ measurements was not discussed technically in these previous studies. Moreover, there has been no discussion of the mashlaha in relation to the CreditRisk+ method.

The risk classification of each customer is an important step in implementing the credit risk model, especially for financial institutions that do not have a complete list of customer portfolios. Each credit risk measurement model has its own classification method, therefore the same credit can be classified differently by different models. The question is whether this classification significantly influences the size of the credit risk (Saunders and Allen, 2002). The determination of the band and its group on CreditRisk+ has no absolute provisions. Crouchy and Saunders demonstrate differences in determining the band. In contrast, however, in the CreditRisk+ guide book there is no absolute determination of the band.

Research by Melaini (2010) divided the band with a classification of Rp. 1,000,000 and Rp. 10,000,000, though this determination was not for any particular reason. The impact that occurs is that the backtesting estimation results show a measurement error of four times (Melaini, 2010). The same thing was done by Rochman (2010), whereby the bands were classified without taking any other perspectives into consideration. Estimated errors occur, thus the accuracy of CreditRisk+ calculations depend on the band classification method used.

The existence of different bands will affect the accuracy of CreditRisk+ measurements in Islamic financial institutions (Sofyan et al., 2017). The measurement of credit risk in Islamic financial institutions is not much different from conventional ones where such measurements can be done 
using traditional and Value at Risk (VAR) methods (Sundararajan, 2007). VAR does have its own calculation in measuring risk, but the VAR intended in several studies of credit risk calculation methods is how a method can get an unexpected loss value.

The method put forward by Sundararajan (2007) is not in accordance with what was produced by this study, where the relationship with the accuracy of measurement of financing risk is adjusted to the probability of each event. These approaches are very different, for example the probability of possible default on financing that has collateral and has no guarantee. Besides that, the measurement of credit risk in conventional institutions paying attention to the impact of changes in interest rates and the macro economy. While in contrast, Islamic financial institutions do not take this into account.

The accuracy of CreditRisk+ is suitable for use in Islamic finance institutions because the probability of an event should be the same for each exposure because it is based on the Poisson distribution (Sugito and Mukid, nd). However, the weakness of the Poisson distribution is that if the probability is not the same for all units, then the negative binomal distribution is more suitable to use (Darmawi, 2016). Thus, if the CreditRisk+ framework is applied to a bank financial institution that has a variety of financing products, it can cause estimation errors.

\section{RESEARCH METHODS}

We utilize both qualitative and quantitative methods by analysing deductively and categorizing monthly data into a band group. In addition, we also utilize a qualitative analysis of mashlaha concept from Abu Zahrah concept about maqashid al-sharia. The object of this research is an Islamic financing institution in Makassar, PT XYZ. The data obtained is the data of debtors who conducted financing between January 2014 to December 2016.

\section{Data Analysis}

The process of measuring risk financing using the CreditRisk+ method has several stages as follows:

1. Preparation of bands, conducted to classify total exposure into several groups based on the amount of financing exposure.

2. The Default Rate is the default occurrence value that occurs in each band group. Mathematically, the calculation of the default rate (Kurniawan, 2009) is stated as follows: 
IQTISHADIA

12,2

\section{8}

(1)

$$
\lambda=\frac{\text { EAD Each band group }}{\text { unit of exposure } \mathrm{X} \text { band group unit }}
$$

3. Recovery Rate, is the percentage of default financing that can be paid back (Kurniawan, 2009).

(2) $\frac{\text { default financing that was successfully billed }}{\text { default total financing }}=100 \%$

4. Loss Given Default / Actual Loss, is the level of loss caused by default. (Imansyah and Mara, 2007):

(3) $\quad$ LGD = financing value $\mathrm{x}(1$ - recovery rate $)$

5. Probability of Default and Cumulative Probability of Default, the calculation is done using the Poisson distribution model in each group each period (Manurung, Ariswoyo, and Sembiring, 2013):

$$
\operatorname{prob}(n \text { default })=\frac{e^{-m} m^{n}}{n !}
$$

Where:

$\mathrm{e}=$ number exponential $=2.71828$

$\mathrm{m}=\lambda=$ average number of defaults for each band per period

$\mathrm{n}=$ number of default debtors where $\mathrm{n}=\mathrm{0}, 1,2,3, \ldots, \mathrm{N}$

$!=$ factorial

6. Expected Loss and Unexpected Loss. Expected loss is a predictable loss that is based on historical data on the number of default events in each band. Unexpected loss is the amount of loss from the default event that is used if the cumulative probability of default value has reached the 95\% - 99\% confidence level.

(5) Expected/Unexpected Loss (EL) $=\mathrm{n} \times$ unit of exposure $\mathrm{x}$ unit band

with $\mathrm{n}=$ expected/unexpected number of default

7. Economic Capital, is the amount of capital that must be prepared to anticipate losses due to unexpected loss:

(6) Economic capital $=$ unexpected loss - expected loss 
8. Backtesting, is to compare the predicted risk value with the actual Mashlaha risk value based on a certain level of confidence (Jorion, 2007). Backtesting is done by comparing the value of unexpected loss with the actual loss / LGD value. If the actual loss value < unexpected loss value means the unexpected loss value can cover the actual loss.

\section{in Financing \\ Risk}

249

9. Model Validation, inspection process to ascertain whether the model is still feasible / appropriate to be used, carried out by Loglikelihood Ratio (LR) Test the following causes (Jorion, 2007):

(7)

$$
c R_{u c}=-2 \ln \left[(1-p)^{r-N} p^{v}\right]+2 \ln \left\{\left[1-\frac{\alpha}{r}\right]^{r-N}\left(\frac{N}{r}\right)^{N}\right\}
$$

Where:

$\mathrm{uc}=$ The probability of errors under the null hypothesis

$\mathrm{N}=$ Number of estimated error frequencies

$\mathrm{T}=$ Amount of data

The LR value is compared with the chi-square value (with free degrees at the expected level of significance level). The hypothesis for LR testing is:

1. If the LR value is < chi-square critical value, then the CreditRisk+ model is accepted.

2. If the $L R$ value is $>$ critical chi-square value, then the CreditRisk+ model is rejected.

\section{RESULT AND DISCUSSION}

\section{Quantitative Findings}

The financing data analyzed are from January 2014 to December 2016 with a 36-month observation period. The outstanding financing value at PT XYZ is as follows:

\section{Table 1.}

Total Outstanding Financing of PT. XYZ (in Rupiah)

\begin{tabular}{lll}
\hline \multicolumn{1}{c}{ Month } & \multicolumn{1}{c}{$\mathbf{2 0 1 4}$} & \multicolumn{1}{c}{$\mathbf{2 0 1 5}$} \\
January & $1,101,189,552,056$ & $430,492,317,192$ \\
February & $1,039,108,019,490$ & $448,880,346,590$ \\
March & $774,832,428,037$ & $430,624,864,515$ \\
April & $688,595,464,592$ & $410,564,853,392$
\end{tabular}




\begin{tabular}{clll}
\hline $\begin{array}{c}\text { IQTISHADIA } \\
12,2\end{array}$ & May & $748,065,522,602$ & $393,248,802,546$ \\
& June & $739,462,375,551$ & $380,094,474,043$ \\
& July & $981,611,979,430$ & $373,289,459,973$ \\
\multirow{2}{*}{$\mathbf{5 0}$} & August & $932,261,719,472$ & $366,598,360,346$ \\
\hline & September & $672,290,160,437$ & $358,684,186,844$ \\
& October & $542,416,145,169$ & $349,448,895,560$ \\
& November & $493,860,670,943$ & $336,868,684,365$ \\
& December & $503,536,445,639$ & $324,963,329,527$ \\
\hline
\end{tabular}

Source: PT XYZ financing database (2017)

The development of PT XYZ's business over the past three years showed a poor performance. The table above shows a sharp decline from the beginning of 2014 in total financing receivables of $\mathrm{Rp} 1,101,189,552,056$ sharply decrease to $\operatorname{Rp} 203,065,463,363$. This was caused by several government policies and the OJK (Financial Services Authority) regulations which applied strict supervision on financing companies such as OJK Regulation Number 29/ POJK.05/2014 about the Implementation of Business Financing Companies. The distribution of bands for financing is carried out for all financing with the default category (collectability E and F) using data from January 2014 to December 2016 and carried out every month. The distribution bands for 2014, 2015 and 2016 were Rp. 2,000,000, Rp. 10,000,000, and Rp. 250,000,000 respectively.

Table 2.

Number of Events or Customers per Group of each Band

\begin{tabular}{cccc}
\hline Group & $\mathbf{2 0 1 4}$ & $\begin{array}{c}\text { Number of customers } \\
\mathbf{2 0 1 5}\end{array}$ & $\mathbf{2 0 1 6}$ \\
Rp 2,000,000 & 7 & 7 & 7 \\
Rp 4,000,000 & 20 & 15 & 15 \\
Rp 6,000,000 & 8 & 12 & 11 \\
Rp 8,000,000 & 11 & 3 & 7 \\
Rp 10,000,000 & 8 & 3 & 7 \\
Rp 20,000,000 & 131 & 40 & 30 \\
Rp 30,000,000 & 219 & 67 & 37 \\
Rp 40,000,000 & 81 & 60 & 25 \\
Rp 50,000,000 & 85 & 36 & 35 \\
Rp 60,000,000 & 47 & 36 & 16 \\
Rp 70,000,000 & 30 & 28 & 20 \\
Rp 80,000,000 & 23 & 32 & 27 \\
Rp 90,000,000 & 34 & 23 & 24 \\
Rp 100,000,000 & 28 & 18 & 26 \\
Rp 110,000,000 & 35 & 20 & 35 \\
Rp 120,000,000 & 28 & 19 & 21 \\
Rp 130,000,000 & 22 & 9 & 26 \\
Rp 140,000,000 & 26 & 20 & 31
\end{tabular}




\begin{tabular}{|c|c|c|c|}
\hline Rp 150,000,000 & 15 & 15 & 25 \\
\hline $\operatorname{Rp} 160,000,000$ & 13 & 11 & 21 \\
\hline Rp 170,000,000 & 9 & 10 & 21 \\
\hline $\operatorname{Rp} 180,000,000$ & 13 & 14 & 16 \\
\hline $\operatorname{Rp} 190,000,000$ & 10 & 7 & 12 \\
\hline Rp 200,000,000 & 14 & 5 & 12 \\
\hline Rp 250,000,000 & 23 & 24 & 60 \\
\hline $\operatorname{Rp} 500,000,000$ & 19 & 21 & 33 \\
\hline $\mathrm{Rp} 750,000,000$ & 14 & 7 & 5 \\
\hline $\operatorname{Rp} 1,000,000,000$ & 1 & 4 & 3 \\
\hline
\end{tabular}

Source: Data processed, 2017.

The next step is to calculate the recovery rates as shown in Table 3 below:

Table 3.

Recovery Rate

\begin{tabular}{ccc}
\hline Year & $\begin{array}{c}\text { The Total withdrawal of the } \\
\text { Redeemed }\end{array}$ & Recovery Rate \\
2014 & $6,258,123,279$ & $10 \%$ \\
2015 & $832,547,294$ & $1 \%$ \\
2016 & $558,922,271$ & $1 \%$ \\
\hline
\end{tabular}

Source: Data on stock pulls and ransom of PT XYZ (2017)

In measuring the risk of financing using the CreditRisk + method, the actual loss (loss given default) is used as a measure of the actual loss for each default event. The value of loss given of default is obtained by subtracting the value of financing at default with the value of the recovery rate, for example in Table 3 the value of financing is stalled in April: 46,314,250,00o X (1-10\%) $=41,657,644,275.84$

The results of the monthly loss given default calculation are in Table 4 below:

Table 4.

Results Loss Given Default by Month

\begin{tabular}{clccc}
\hline No & Month & \multicolumn{1}{c}{2014} & \multicolumn{1}{c}{2015} & 2016 \\
1 & January & $65,371,702,250.15$ & $53,718,037,616.42$ & $73,009,310,507.03$ \\
2 & February & $69,378,711,959.52$ & $60,753,001,642.76$ & $74,344,666,606.06$ \\
3 & March & $56,434,207,614.77$ & $60,682,793,140.21$ & $76,326,458,221.79$ \\
4 & April & $41,657,644,275.84$ & $61,773,647,221.31$ & $76,799,100,809.01$ \\
5 & May & $30,916,958,820.60$ & $61,386,113,738.93$ & $73,941,138,090.22$
\end{tabular}




\begin{tabular}{ccllll}
\hline IQTISHADIA & & & & & \\
12,2 & 6 & June & $63,701,214,227.65$ & $61,590,515,143.96$ & $74,645,787,596.80$ \\
& 7 & July & $66,043,976,208.37$ & $65,711,897,970.96$ & $77,216,948,310.22$ \\
& 8 & August & $70,617,428,777.41$ & $66,313,883,360.41$ & $78,226,990,315.67$ \\
& 9 & September & $73,775,050,003.87$ & $67,718,214,822.94$ & $80,020,732,688.94$ \\
252 & 10 & October & $54,357,422,352.96$ & $68,322,327,999.94$ & $80,704,242,865 \cdot 91$ \\
& 11 & November & $64,237,270,449.08$ & $68,929,692,568.66$ & $81,145,472,535 \cdot 40$ \\
& 12 & December & $55,984,699,765.00$ & $70,304,080,517.00$ & $83,082,251,408.00$ \\
\hline
\end{tabular}

Source: Data processed, 2017.

Table 4 above shows the general loss given and fluctuating default values. One significant factor in these fluctuations is the recovery rate. Thus, it can be concluded that the greater the recovery rate, the smaller the loss given default, and vice versa.

Capital adequacy (economic capital) is capital that must be owned by the company to cover the value of losses caused by unexpected loss. This economic capital is the capital needed in calculating financing risk with CreditRisk + model. The economic capital value is derived from the difference between unexpected loss and expected loss. Table 5 below illustrates the calculation of Economic capital values:

Table 5.

Number of Expected Loss, Unexpected Loss, and Economic Capital

\section{Year 2014}

$\begin{array}{cccc}\text { Month } & \text { Expected loss } & \text { Unexpected loss } & \begin{array}{c}\text { Economic } \\ \text { capital }\end{array} \\ \text { January } & 72,686,660,000 & 112,298,000,000 & 39,611,340,000 \\ \text { February } & 76,792,960,000 & 118,052,000,000 & 41,259,040,000 \\ \text { March } & 63,281,500,000 & 98,752,000,000 & 35,470,500,000 \\ \text { April } & 46,311,400,000 & 79,202,000,000 & 32,890,600,000 \\ \text { May } & 34,911,580,000 & 62,030,000,000 & 27,118,420,000 \\ \text { June } & 71,221,700,000 & 110,394,000,000 & 39,172,300,000 \\ \text { July } & 73,424,660,000 & 112,738,000,000 & 39,313,340,000 \\ \text { August } & 78,497,140,000 & 119,210,000,000 & 40,712,860,000 \\ \text { September } & 82,018,710,000 & 123,876,000,000 & 41,857,290,000 \\ \text { October } & 60,433,780,000 & 97,994,000,000 & 37,560,220,000 \\ \text { November } & 71,416,600,000 & 112,716,000,000 & 41,299,400,000 \\ \text { December } & 62,214,980,000 & 100,778,000,000 & 38,563,020,000\end{array}$




\begin{tabular}{|c|c|c|c|}
\hline \multicolumn{4}{|c|}{ Year 2015} \\
\hline January & $54,394,460,000$ & $92,028,000,000$ & $37,633,540,000$ \\
\hline February & $61,552,520,000$ & $100,524,000,000$ & $38,971,480,000$ \\
\hline March & $61,268,740,000$ & $100,940,000,000$ & $39,671,260,000$ \\
\hline April & $62,413,900,000$ & $101,466,000,000$ & $39,052,100,000$ \\
\hline May & $62,016,960,000$ & $99,426,000,000$ & $37,409,040,000$ \\
\hline June & $62,314,080,000$ & $100,900,000,000$ & $38,585,920,000$ \\
\hline July & $66,231,320,000$ & $105,974,000,000$ & $39,742,680,000$ \\
\hline August & $67,127,620,000$ & $105,926,000,000$ & $38,798,380,000$ \\
\hline September & $68,394,400,000$ & $107,058,000,000$ & $38,663,600,000$ \\
\hline October & $69,006,380,000$ & $109,372,000,000$ & $40,365,620,000$ \\
\hline November & $69,739,360,000$ & $110,842,000,000$ & $41,102,640,000$ \\
\hline December & $69,065,420,000$ & $110,918,000,000$ & $41,852,580,000$ \\
\hline \multicolumn{4}{|c|}{ Year 2016} \\
\hline January & $74,139,340,000$ & $112,801,800,000$ & $38,662,460,000$ \\
\hline February & $75,090,480,000$ & $113,900,200,000$ & $38,809,720,000$ \\
\hline March & $77,481,480,000$ & $116,410,400,000$ & $38,928,920,000$ \\
\hline April & 79,391,707,301 & $116,260,400,000$ & $36,868,692,699$ \\
\hline May & $76,391,600,000$ & $113,330,000,000$ & $36,938,400,000$ \\
\hline June & $76,454,780,000$ & $113,501,600,000$ & $37,046,820,000$ \\
\hline July & $79,218,600,000$ & $117,098,200,000$ & $37,879,600,000$ \\
\hline August & $79,786,360,000$ & $115,899,600,000$ & $36,113,240,000$ \\
\hline September & $80,918,601,620$ & $121,550,600,000$ & $40,631,998,380$ \\
\hline October & $81,490,241,620$ & $122,050,000,000$ & $40,559,758,380$ \\
\hline November & $81,687,161,620$ & $123,122,200,000$ & $41,435,038,380$ \\
\hline December & $83,656,400,000$ & $125,552,800,000$ & $41,896,400,000$ \\
\hline
\end{tabular}

Mashlaha in Financing Risk

\section{Source: Data processed, 2017.}

From the calculation above, the average fund issued for clients by PT XYZ is Rp. 36,643,374,154 yearly. Economic capital can be determined as an indicator obtained from income activities, the acquisition of profit margins paid by the customer each transaction and capital period determined by PT XYZ in anticipation of the loss that must be borne against unexpected events. This can be done by comparing the projection of the unexpected loss value with the loss given default/actual loss every month during the period January 2014 - December 2016. If the loss given default value exceeds 1\% of the unexpected loss value then the model is said to be quite good at predicting financial risk. However, if a loss given default exceeds $10 \%$ of the unexpected loss, then the model is doubtful. Graphical depiction of the comparison of unexpected loss measurement projections with loss given default as follows: 
IQTISHADIA

12,2

254
Figure 2.

Backtesting a CreditRisk+ Model

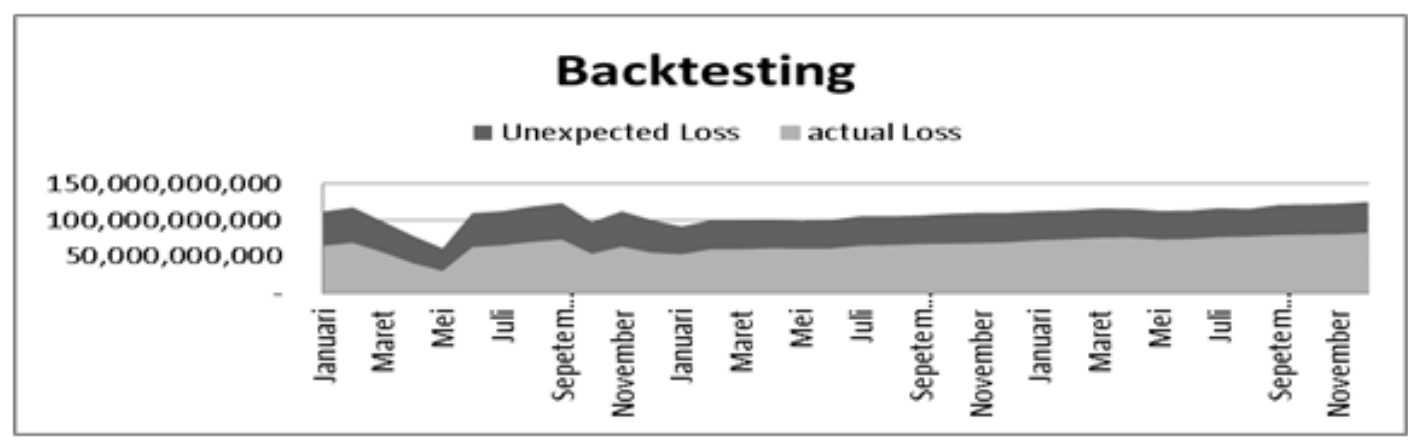

Source: Data processed, 2017.

Figure 2 illustrates the unexpected loss and expected loss charts in backtesting. The picture above shows the model used in this study is still transparent, as seen in the nominal loss given default there is no more than the unexpected loss value of $99 \%$ in the observation period. This is because the level of confidence used is $99 \%$ above the standard that usually used at $95 \%$. With a confidence level of $99 \%$, the value of unexpected loss is greater and the difference with loss given default is wider. The selection of a confidence level of $99 \%$ is based on the need for a greater range of unexpected loss to ensure the company's financial condition is maintained from the worst possible risk of financing.

Furthermore, the Log Likelihood Ratio Test is conducted to evaluate the accuracy of CreditRisk+ models in estimating unexpected loss. The Log Likelihood Ratio Test calculates the actual loss value that exceeds the unexpected loss every month and then compares the maximum incidence of errors that can be tolerated during the observation period. In this case, the data needed is the observation period every month, the number of errors from the calculation of loss given default exceeds the unexpected loss, and the level of confidence used.

Table 6.

Measurement of Loglikelihood Ratio Test

\begin{tabular}{cc}
\hline Explanation & Result \\
T (Number of Observation Periods) & 36 Bulan \\
V (Amount of Data Error) & 0 \\
P (Probability of Error) & 0.01 \\
Loglikelihood Ratio & 0 \\
Critical Chi Square & 6.634896712 \\
\hline
\end{tabular}

Source: Data processed, 2017 
From the measurement results we obtained a value of o (zero) $<6.634896712$ (critical value of chi square), the probability level of 0.01 or 99\%. Thus, it can be concluded that CreditRisk + is able to measure PT XYZ's financing risk accurately.

\section{Mashlaha in Financing Risk Measurement}

This research reveals several problems when measuring risk is carried out in Islamic finance institutions, using the CreditRisk+ method. To fulfill the attainment of the essential mashlaha, the achievement of mashlaha, and rejection of mafsadah is needed. Both are complementary rather than reciprocal: if the elimination of mafsadah is done, then mashlaha materializes (Syarif and Ahmad, 2016). This problem is inseparable from the rules of fiqh from dar'u al-mafasid muqaddam 'ala jalb al-masalih, that promote the prevention of damage, the principle of Islamic teachings. The use of CreditRisk+ methods in measuring financing risk is the right thing to do, because it provides information on the condition of a financing company accurately, especially when a company experiences liquidity problems that can result in the emergence of mafsadah mal (loss/loss of pr operty).

\section{Maqashid al-sharia according to Abu Zahrah's perspective: Tahdzib al-Fard (Individual Education)}

Credit risk measurement is dominated by credit rating agencies. However, independent risk measurement by sharia financing institutions is one of the risk management solutions in achieving the mashlaha. Although each financing institution has a risk management division, estimating losses is a separate discipline. Islam teaches to gain knowledge (al-Qur'an, al-Mujadalah: 11; Ali Imran: 18; Thaha: 114; and al-Zumar: 9). The Prophet Hadith also stated thalabul ilmi faridatun as ala kulli Muslim wa Muslimatin (HR. Ibn Majah). Suyuthi, Abd al-Ghani, and Fakhru al-Hasan (n.d) explained that this hadith was not binding to the science of worship alone, but could be applied to general sciences.

Other hadiths of the Prophet also indicate that Thalhah Bin 'Ubaidah r.a. said "I and the Messenger of Allah walked past several palm groves, then the Prophet asked" What did they do? "The surrounding people answered" They pollinate by making male seeds enter into the female seed, until it becomes pollinated. The Messenger of Allah said "I suspect, if they leave it, it might be better", Then they let it go, and the results of the dates diminish. They asked the Prophet, and the Messenger of Allah said "If the pollination 
IQTISHADIA

12,2

256

is indeed beneficial for them, then do it in fact I just guessed, don't take the guess I made, But if I tell you something that comes from God, then take it, I really will never lie for what came from God (in another history the Prophet said "You know more about your world affairs)" (HR. Muslim). Nawawi $(1402 \mathrm{H})$ describes this hadith in Muslim-style syarah al-Nawawi that all 'world affairs' that are not related to sharia law (halal, haram, legitimate, corrupt) should one try to deepen themselves by trying and conducting various experiments in order to achieve success.

To carry out risk measurement independently and achieve compliance with the requirements of al-Aql, conducting training as a form of prevention of mafsadah is a must. This is supported by Firdaus's research (2012) that maximum learning orientation in a maintained perspective of reason requires a balanced supply of food for the mind and heart, not overstating one another. The learning process which overemphasizes reason without involving the heart is proven to have a negative and fatal impact on the organization. In addition, the Indonesian Government also stressed through OJK that it issued regulations for financial institutions to carry out active risk management listed in the OJK Regulation Number 1/POJK.05/2015 concerning the Implementation of Risk Management for Non-Bank Financial Services Institutions. Even in Article 6 it is said that financial institutions must conduct self-assessments at least once a year.

In conclusion, when PT. XYZ uses the CreditRisk+ method in estimating the potential risks that may arise from problem financing, PT. XYZ has implemented the concept of tahdzib al-fard.

\section{Iqamah al-Adl (Enforcement of Justice)}

Iqamah al-adl is also one of the principles of risk management (Ahmad and Yaacob, 2012). A concrete example of this problem is the 2008 financial crisis, also known as the subprime mortgage crisis caused by the high lending rates charged to lower-class income borrowers. Utilizing a higher interest rate is one way that financial institutions avoid the risk of loss when the debt is not settled. Loans given to people who did not meet the requirements and could not afford to repay are reflective of the occurrence of oppression and injustice because these groups will be subject to higher fees judging by their high risk profile (Ahmad and Yaacob, 2012). As in the previous preliminary study, the measurement of risk by the Default Mode method will only have implications for the information on the condition of the financial institution. Many credit ratings do this method in developed countries (Alessi, 2013). 
This premise encourages muslim investors and stakeholder institutions to obtain credit ratings from leading international credit rating agencies in making investment decisions (Radzi and Lonik, 2017). However, credit rating agencies experienced a crisis of confidence due to rating reporting on Lehman Brother's Bank which resulted in the 2008 financial crisis (Cukierman, 2010). Transparency in measuring risk is needed, because it is not in accordance with sharia principles otherwise. This principle encourages humanity to carry out risk measurment honestly and in a transparent manner. Therefore, they will always be honest and will not cheat for their own benefit. So, all acts of cheating that are contrary to the principle of transparency are hated by Islam (Ahmad and Yaacob, 2012). Thus, the lack of credit rating agencies to increase the transparency of Islamic financial markets and improve corporate governance must be immediately addressed by the international regulatory community (Radzi and Lonik, 2017).

Three years before the 2008 financial crisis, Obaidullah (2005) conducted a study of rating transparency for Islamic banking. According to him, the prediction of corporate bankruptcy is an important and widely studied topic because it can have a significant impact on bank's loan decisions and profitability. The traditional approach for banks for credit risk assessment is to produce internal assessments, which take into account various aspects of quantitative and subjective factors, such as leverage, income, and reputation, through a valuation system. The problem with this approach is of course the inconsistency and duplication of efforts related to these predictions. At the same time, using ratings issued by standard credit rating agencies, such as Moody's and Standard \& Poor's is considered problematic, because these ratings tend to be reactive rather than predictive. In order for agencies to change debt ratings, they generally wait until they have very high trust/ evidence to support their decisions. Thus, there is a need to develop a quantitative predictive model that is sufficiently accurate and can function as an early warning signal for the default counterparty.

The same thing was expressed by Radzi and Lonik (2016) who argued that international credit rating agencies still need further development and refinement of Islamic bank ratings, because compliance with sharia values is not part of the authority of these institutions. This is important to be considered by international rating agencies in order to distinguish between the conventional banking industry and the Islamic finance industry. A special mechanism needs to be designed to classify institutions and products that comply with Islamic sharia by observing the Islamic Financial Services standards that govern this industry. 
IQTISHADIA

12,2

258

The major credit rating agencies must show that their analysts have expertise relevant to the Islamic finance industry sector. Otherwise, the credit ratings issued by these institutions will not be accepted because they do not reflect the truth and because they are not consistent with the IFSB guidelines (Islamic Financial Services Board) and result in limited use for investors and other stakeholders in the Islamic community.

\section{Mashlaha (Public Interest)}

Related to the principle of risk management, Islam prioritizes prevention rather than recovery. Al-Qur'an also discusses the application of risk management (Surah Yusuf: 47-49, and QS. Al-Baqarah: 282) especially those that are protective credit risk (Agha and Sabirzyanov, 2015). In addition, the principle of risk management also exists in the hadith of the Prophet SAW: When he was asked: O Messenger of Allah, should I leave my camel, untied and trust in Allah, or should I tie it up? The Holy Prophet answered: Tie your camels and then believe in Allah (HR. Tirmidhi). Despite the fact that a Muslim must believe in Allah SWT, this hadith proves that a Muslim should not be passive and fatalist. This Hadith not only describes how a Muslim must be responsible for his destiny, but also instructs to manage risks, catastrophes, and losses.

Risk management does not conflict with the concept of tawakkal (trust in Allah SWT). Tawakkal is choosing the right way to achieve your goal, then trusting God for better results. Not only that, Islamic principles also discuss the fiqh rules: la dharar wa la dirar with the derivation of the rule from u mafasid muqaddam ala jalb masalih (Asen, 2017). The rules of fiqh alghunmu bi al-ghurmi (for every profit there will be risks associated with it) and al-kharaj bi al-daman (income is compensation for the responsibility taken), and risk is inseparable from economic activity (Dusuki, 2012; Shaharuddin, 2016).

Regarding the Islamic literature above, the concept of predictive risk measurement such as CreditRisk+ certainly has a disadvantage, namely calculating risk after the default occurs. For this reason, additional methods are needed to create good risk management. Sundararajan (2007) also suggested that a combination of methods can be done so that a more proactive risk management process occurs. However, the practice of combining these methods is rarely found in financing companies. Generally, financing companies do not require quantitative calculations, which is different from the banking required by BASEL II regulations. 
To create good risk management, we need several other methods of measuring risk, such as those carried out by Oktavina et al., (2014), Nosratabadi et al., (2012) and Maholtra and Maholtra (2002). The results of their research indicate a good impact on internal auditing and measuring the risks that exist. According to Munteanu (2006), the qualitative method is also very easy to apply, understand and is low cost.

In addition, according to Măzăreanu (2007), aspects of the human factors (all related aspects, such as professionalism, ability skills, and psychological factors) are also significantly needed in measuring risk. However, qualitative and quantitative approaches, both cannot be separated from subjective judgments (Munteanu, 2006). In a quantitative approach, stages are found where there is a need to make an estimate and judgment from the researcher to assess the value of assets, the value of competitive assets, the cost of software, and the cost of protecting it. So, quantitative measurements are suitable for use by Islamic finance institutions. The absence of a risk measurement process at a financial institution will lead to greater systemic risk. This is illustrated by the practice of shadow banking conducted in Indonesia, a finance company that distributes credit to customers by using several sources of funds (equity, bonds, as well as working capital loans from banks). Because of the practice of shadow banking, not only finance companies can be affected if a problem occurs, but other related financial institutions can also be affected (Adriyanto, 2012).

Therefore, the process of measuring risk in risk management activities is realized in the objectives of the sharia that protect human welfare. The concept of mashlaha in the perspective of Maqashid al-sharia as a promotion of people's welfare, lies in maintaining their faith (din), themselves (nafs), their intellect (' $a q l$ ), their lineage (nasl) and their wealth (mal) (Agha and Sabirzyanov, 2015).

\section{CONCLUSION}

It can be concluded that CreditRisk+ is able to measure PT XYZ's financing risk accurately. Furthermore, the method is in line with the concept of maqashid al-sharia according to Abu Zahrah's perspective, namely 1) Tahdzib al-fard, that is to make financial institutions capable independently of measuring the risk of their own financing; 2) Iqamah al-Adl, having measurements independently will create information, while comparing the results of measurements both internally and externally. 3) Mashlaha which 
IQTISHADIA

12,2

260

is in the public interest and the measurement of risk internally will reduce systemic risks that can potentially occur within the Islamic finance sector. The combination methods of conventional and sharia ones in assessing risk on financing risk will provide more proactive management risk.

\section{References}

Abu Zahrah, Muhammad. (1997). Ushul al-Fiqh. Dar al-Fikr al-Arabi, Cairo. Adriyanto. (2012). Penyaluran Kredit Non Perbankan dan Pertumbuhan Ekonomi: PerspektifBadan Kebijakan Fiskal Kementerian Keuangan. Kajian Fiskal, Jakarta.

Agha, Syed Ehsan Ullah \& Ruslan Sabirzyanov. (2015). Risk Management in Islamic Finance: An Analysis from Objectives of Sharia Perspective. International Journal of Business, Economics and Law, 7 (3).

Ahmad, Islam Azlin Alisa and Salmy Edawati Yaacob. (2012). The Principle of Risk Management: Sharia Perspectives. Journal of Applied Sciences Research, 8 (7).

Alamsyah, Halim. (2012). Perkembangan dan Prospek Perbankan Syariah Indonesia: Tantangan dalam Menyongsong MEA 2015. Disampaikan dalam Ceramah Ilmiah Ikatan Ahli Ekonomi Islam (IAEI) Milad ke-8 IAEI, 13 April.

Alessi, C. (2013). The Credit Rating Controversy. Campaign 2012. Council on Foreign Relations, New York.

Allen, D. E. and R. J. Powell. (2011). Credit Risk Measurement Methodologies, 19th International Congress on Modelling and Simulation, Perth, Australia, 12-16 December 2011, http://mssanz.org.au/modsim2011

Ascarya. (2006). Akad dan Produk Bank Syariah Konsep dan Praktek di Beberapa Negera. Bank Indonesia, Jakarta.

Asen, Adem. (2017). An Overview of Economic Policy of "Injury (Damage) May Not Be Met by Injury in Islam (La Darar wa La Dirar fi'l-Islam). International Journal of Islamic Economics and Finance Studies, 3 (1).

BaselCommittee on Banking Supervision. (2011). Messages from the Academic Literature on Risk Measurement for the Trading Book.Working Paper No. 19, Bank for International Settlement, 31 January.

Bauer, Rob and Daniel Hann. (2010). Corporate Environmental Management and Credit Risk. Available at SSRN: https://ssrn.com/ abstract $=1660470$ or http://dx.doi.org/10.2139/ssrn.1660470. 
Bodnar, Gordon M., Erasmo Giambona., John Robert Graham., Campbell R. Harvey, and Richard C. Marston. (2011). Managing Risk Management. (March 15, 2011). AFA 2012 Chicago Meetings Paper. Available at SSRN: https://ssrn.com/abstract $=1787144$ or http://dx.doi. org/10.2139/ssrn.1787144.

Crouchy, Michel et al., (2000). Risk Management. McGraw-Hill, New York.

Mashlaha in Financing Risk

Cukierman, Alex. (2010). The Roles of Ideology, Institutions, Politics, and Economic Knowledge in Forecasting Macroeconomic Developments: Lessons from the Crisis. Presented at the November 2009 CESI for Economic Studies Conference on: What's Wrong with Modern Macroeconomics? Munich. Germany.

Darmawi, Herman. (2016). Manajemen Risiko. Bumi Aksara, Jakarta.

Dhruba, Purkayastha. (2018). Managing Credit Risk and Improving Access to Finance in Green Energy Projects, ADBI Working Paper Series No. 855, August 2018.

Direktur Bank Indonesia. (2008). Buku Laporan Keuangan Perekonomian Tahun 2008. Bank Indonesia, Jakarta.

Drehmann, Mathias., Kleopatra Nikolaou. (2009). Funding Liquidity Risk Definition And Measurement, European Central Bank Working Paper Series, No. 1024/March. Retrieved from http://www.ecb.europa.eu or from the Social Science Research Network electronic library at http:// ssrn.com/abstract_id=1338092.

Dusuki, Asyraf Wajdi. (2012). Principles and Application of Risk Management and Hedging Instruments in Islamic Finance. Islamic Economics \& Finance Pedia. http://www.iefpedia.com.

Faisal. (2011). Restrukturisasi Pembiayaan Murabahah dalam Mendukung Manajemen Risiko sebagai Implementasi Prudential Principle Pada Bank Syariah di Indonesia. Jurnal Dinamika Hukum, 11 (3).

Financial Stability Board. Shadow Banking: Strengthening Oversight and Regulation. FSB, Basel.

Firdaus, Achmad. (2012). Mashlaha Peforma (Map) Sistem Kinerja untuk Mewujudkan Organisasi Berkemaslahatan. DeepPublish, Yogyakarta.

Fischer, Matthias, Thorsten Moser, Marius Pfeuffer. (2018). A Discussion on Recent Risk Measures with Application to Credit Risk: Calculating Risk Contributions and Identifying Risk Concentrations, Risks, 6, 142; doi:10.3390/risks6040142. Retrieved from www.mdpi.com/journal/ risks. 
IQTISHADIA

12,2

262

Fitri, Yuda Septia. (2004). Analisis Perhitungan Risiko Kredit dengan Pendekatan CreditRisk+ Portfolio (Studi kasus pembiayaan Ba'i Bithaman Ajil pada BMT At-Taqwa). Tesis. Program Studi kajian Timur Tengah dan Islam Progam Pascasarjana Universitas Indonesia, Jakarta.

Han, Chulwo O and Jang O Kang. (2014). An Extended CreditRisk+ Framework for Portfolio Credit Risk Management. SSRN. Retrieved from https:// papers.ssrn.com/sol3/papers.cfm?abstract_id=2427489.

Ibn Asyur, Muhammad al-Tahir. (2001). Maqāsid al-Syarîah al-Islamiyyah. Dar al-Nafî̀is, Jordan.

Ibn Manzūr. (1994). Lisān al 'Arab. Cet III. Dār Sadir, Beirut.

Imansyah and Mirza Yuniar Isnaeni Mara. (2007). "Penentuan Bobot Resiko Kredit untuk Rumah Tinggal: Studi Kasus di Indonesia,” Bank Indonesia, Jakarta. Working Paper, 10 (1).

Jorion, Philip. (2007). Value at Risk. McGraw-Hill, New York.

Kuritzkes, Andrew., Til Schuermann., and Scott M. Weiner. (2002). Risk Measurement, Risk Management and Capital Adequacy in Financial Conglomerates, Working Paper Presented at the Netherlands-United States Roundtable on Financial Conglomerates, October 23-25, 2002, Washington D.C., Brookings-Wharton Papers on Financial Services.

Kurniawan, Indra. (2009). Analisis Perhitungan Credit Risk+ untuk Kredit Bisnis Mikro pada Bank Rakyat Indonesia. Tesis. Fakultas Ekonomi Universitas Indonesia, Jakarta.

Lathif, Ah. Azharuddin. (2012). Konsep dan Aplikasi Akad Murâbahah Pada Perbankan Syariah di Indonesia. Jurnal Ahkam, 7 (2).

Maholtra, R. \& Maholtra D.K. (2002). Differentiating between Good Credits and Bad Credits Using Neuro-Fuzzy Systems. European Journal of Operational Research, 136 (1).

Makkulau, Andi Rio and M. Wahyuddin Abdullah. (2017). Penerapan Prinsip Syariah dalam Akad Pembiayaan Murabahah pada Bank Muamalat. Jurnal Iqtisaduna, 3 (1).

Ma'lūf, Louis. (1987). Al Munjid fi al Lugah wa al Adab wa al 'Ulum. Cet. XIX. Mathba'ah al Katulikiyyah, Beirut.

Manan, Siti Khadijah Ab. and Muhammad Hakimi bin Mohd. Shafiai. (2015). "Risk Management of Islamic Microfinance (IMF) Product by Financial Intituions in Malaysia. International Accounting and Business Conference (IABC), Procedia Economics. 
Manurung, Rani et al. (2013). Perbandingan Distribusi Binomial Dan Distribusi Poisson Dengan Parameter yang Berbeda. Saintia Matematika, 1 (3). 300-312.

Măzăreanu, Valentin P. (2007). Risk Management and Analysis: Risk Assessment (Qualitative and Quantitative). Analeleş Tïnţifice Ale Universităţ Ii „Alexandru Ioan Cuza” Din Iaşi Tomul Liv Ştiinţe Economice.

Melaini, Any. (2010). Penerapan Metode Creditrisk+ dalam Pengukuran Risiko Kredit Kendaraan Bermotor (Kasus pada PT ' $\mathrm{X}^{\prime}$ ). Jurnal Organisasi dan Manajemen Universitas Terbuka, 6 (2): 101-118.

Misman, Faridah Najuna and M. Ishaq Bhatti. (2010). Risks Exposure In Islamic Banks: A Case Study Of Bank Islam Malaysia Berhad (BIMB), Australian Centre for Financial Studies - Finsia Banking and Finance Conference. Retrieved from https://papers.ssrn.com/sol3/papers. cfm?abstract_id=1632849.

Mohammad, Mustafa Omar and Syahidawati Shahwan. (2013). The Objective of Islamic Economic and Islamic Banking in Light of Maqasid AlShariah: A Critical Review. Middle-East J. Sci. Res., 13 (Research in Contemporary Islamic Finance and Wealth Management): 75-84.

Munteanu, Adrian. (2006). Information Security Risk Assessment: The Qualitative Versus Quantitative Dilemma. Makalah yang dipresentasikan pada $6^{\text {th }}$ IBIMA Conference.

Nawawi. (1402 H.). Syarah Nawawi ala Muslim. Dar al-Fikr, Beirut.

Nosratabadi, Hamid Eslami Ahmad Nadali, and Sanaz Pourdarab. (2012). Credit Assessment of Bank Customers by a Fuzzy Expert System Based on Rules Extracted from Association Rules. International Journal of Machine Learning and Computing, 2 (5).

Oktavina, Rahma. Retno Maharesi, and Dwi Asih Haryanti. (2014). An Expert System of Risk Assessment on Internal Audit of Sharia Financial Industry in Indonesia. ARPN Journal of Engineering and Applied Sciences, 9 (10).

Olof, Robert. (2006). Penerapan Metode CreditRisk+ dalam Pengukuran Risiko Kredit pada Pembiayaan Kendaraan Bermotor: Studi Kasus PT XYZ”. Tesis. Program Studi Magister Manajemen, Universitas Indonesia, Jakarta.

Oswari, Teddy. (2008). Model Antisipasif Manajemen Risiko Kredit: Variabel Kontinjensi. Doctoral Colloqium: The 3, Doctoral Journey in Management, Jakarta. 
IQTISHADIA

12,2

264

Otoritas Jasa Keuangan. (2015). Peraturan OJK Nomor 1/POJK.05/2015 tentang Penerapan Manajemen Risiko bagi Lembaga Jasa Keuangan Non Bank.

Pirotte, Hugues., Mathias Schmit and Céline Vaessen. (2004). Credit Risk Mitigation Evidence in Auto Leases: LGDvand Residual Value Risk, Working Papers. Retrieved from https://EconPapers.repec.org/ RePEc:sol:wpaper:04-008.

Rachmati, Ika Rosalia. (2012). Penetrasi Praktik Shadow Banking di Indonesia. Jurnal Akuntansi UNESA, 1 (1).

Radzi, Rafisah Mat and Ku Azam Tuan Lonik. (2016). Islamic Banks' Risks: Its Rating Methodology and Shariah Assessment Solutions. Journal of Islamic Banking and Finance, 4 (2): 48-60.

Radzi, Rafisah Mat and Ku Azam Tuan Lonik. (2017). Conventional and Islamic Banks' Risks: Rating Assessment From Credit Rating Agencies. IMPACT: International Journal of Research in Business Management (IMPACT: IJRBM), 5 (2): 37-50.

Rahman, Rashida Abdul Fauzia Hanim Tafri and Yaseen Al Janadi. (2010). Instruments and Risks In Islamic Financial Institutions. Malaysian Accounting Review Special Issue, 9 (2): 11-21.

Rochman, Fatchur. (2010). Analisis Pengukuran Risiko Pembiayaan Murabahah dengan Menggunakan CreditRisk+ (Studi kasus BNI Syariah)". Tesis. Program Magister Manajemen, Universitas Indonesia, Jakarta.

Saunders, Anthony and Linda Allen. (n.d.) Credit Risk Measurement New Approaches to Value at Risk and Other Program. John Willeys \& Sons, New York.

Savvides, Savvakis C. (2011). Corporate Lending and the Assessment of Credit Risk. Journal of Money, Investment and Banking, ISSN 1450288X Issue 20, (C) EuroJournals Publishing, Inc. 2011, http://www. eurojournals.com/JMIB.htm.

Shaharuddin, Amir. (2016). Defining Harmonisation of Shariah Rulings in Islamic Finance. Arab Law Quarterly, 30 (3): 292 - 304.

Sharif, Adnan et al. (2015). Strategi Optimasi Sistem Manajemen Risiko Pembiayaan pada Bank Jabar Banten Syariah. Jurnal MPI, 10 (2).

Sofyan, A Syathir et al. (2017). Akurasi CreditRisk+ Mengukur Risiko Pembiayaan Lembaga Pembiayaan Syariah. Makalah yang dipresentasikan dalam Prosiding Konferensi Nasional Ke-6 Asosiasi Program Pascasarjana Perguruan Tinggi Muhammadiyah. 
Sofyan. A Syathir. (2017). Analisis Risiko Pembiayaan pada Lembaga Pembiayaan Syariah. Tesis. UIN Alauddin Makassar, Makassar.

Spuchláková, Erika., Katarína Valaškováb, Peter Adamko. (2015). The Credit Risk and its Measurement, Hedging and Monitoring Procedia Economics and Finance 24, pp. 675 - 68, doi: 10.1016/S22125671(15)00671-1

Mashlaha in Financing Risk

265

Sugito and Moch Abdul Mukid, (n.d). Distribusi Poisson dan Distribusi Eksponensial dalam Proses Stokastik.” Media Statistika, 4 (2): 113120.

Sugiyono. (2009). Metode Penelitian Kuantitatif dan Kualitatif dan R\&D. Alfabeta, Bandung.

Sundararajan. (2007). Risk Management and Discloure in Islamic Finance and the Implications of Profit sharing Investment Accounts. Proceeding of 6th International Conference on Islamic Economic and Finance, 1.

Suyuthi, Abd al-Ghani, dan Fakhru al-Hasan (n.d), Syarah Sunan Ibn Majah. Qudaimi Kutubu Khaana, Karatisi.

Syarif, Akbar dan Ridzwan bin Ahmad. (2016). Konsep Mashlaha dan Mafsadah sebagai Asas Pemikiran Maqāsid Syariah: Satu Analisis. Jurnal Ijtihad. 10 (2): 1-10.

Wibisono, Wahyu. (2013). Analisis Pengaruh Kebijakan Minimal Uang Muka Kredit (Down Payment) terhadap Volume Penjualan Sepeda Motor di Kabupaten Jombang. Jurnal Akuntansi UNESA, 1 (3).

Winardi, Adityo Nugroho. (2013). Implementasi Prinsip Pembiayaan Kredit Konsumtif \& Strategi Penyelesaian Kredit Bermasalah (Studi di PT BFI Finance Indonesia Tbk, Cabang Kota Malang). Jurnal Ilmiah Mahasiswa Fakultas Ekonomi dan Bisnis Universitas Brawijaya, 2 (1). 